\title{
Institutionalisation and implementation of the selected participatory instruments. The case of Poland
}

Keywords: public participation, new institutionalism, activism, participatory instruments

\begin{abstract}
The article traces the process of the institutionalisation of selected elements of the mechanisms of public participation, whose consequence was the unification of the rules of implementation and formalisation. The process, however, did not result in an increase in civic engagement on the part of the citizens of all the territorial units under consideration. The article presents the outcome of both quantitative and qualitative (in-depth interviews) research conducted by the author in Polish municipalities. The theoretical framework of the article is provided by 'new institutionalism', and especially by 'rational choice institutionalism'. The structure of the article is as follows: the first part focuses on the principles of new institutionalism with reference to the mechanisms of public participation. The second part presents a succinct analysis of the step-by-step institutionalisation of selected participatory mechanisms that have ensued in recent years. The third part contains a methodological overview of empirical research, while the fourth, and final, part includes the outcome of the research and its interpretation.
\end{abstract}

* ORCID ID: https://orcid.org/0000-0003-2105-2953, Ph.D. at the Institute of Political Science, University of Rzeszów, Poland. The fields of her scientific interests include public governance, public participation and civic engagement, cross-sectoral cooperation and public policies (with the special interest in social and education policy). She also conducts research in the field of social entrepreneurship as well as comparative research on social economy systems; anna.kolomycew@ur.edu.pl 


\section{Introduction}

Participation of citizens in decision-making processes is nowadays widely acknowledged. Therefore, what remains engaging as a scholarly question is not 'if' but 'how' one should involve local communities in public affairs. Although public participation is connected with the direct involvement on the part of citizens, it is not by any means limited to forms of direct democracy, but it encompasses instead a range of mechanisms that has seen a considerable growth in recent years. Some of these mechanisms have taken hold in public life, becoming thereby significant and staple institutions. Many of them are of an obligatory nature ${ }^{1}$. Some of the mechanisms, however, are optional, and as such are implemented at irregular intervals. In contrast, other mechanisms are only applied as 'democratic experiments' or 'democratic innovations', whose value lies primary in their educational character, in their redefinition of existing public sphere roles, and in providing a new outlook on the existing shape of the public sphere and on the relations between specific stakeholders ${ }^{2}$.

The institutionalisation of participatory mechanisms, which contributed to their universal implementation and to the relative unification of forms of participation, was also connected with their professionalisation and formalisation, which in turn discouraged citizens from becoming involved in public affairs ${ }^{3}$. Such reluctance was primarily exhibited by the less educated, by the less represented, or those who are less able to deal with all the formalities involved. As a result, this lack of knowledge and experience connected with the functioning of the public sphere simply excludes some residents from influencing the public issues ${ }^{4}$.

1 J. Landry, L. Angeles, Institutionalizing Participation in Municipal Policy Development: Preliminary Lessons from a Start-Up Process in Plateau-Mont-Royal, «Canadian Public Policy» 2011, No. 20 (1), pp. 105-130; M. Salvador, C. Ramió, Institutional Design of Citizen Participation in Local Administration: Reflections from a Case Study, «Revista del CLAD Reforma y Democracia» 2012, No. 53 (53), pp. 165-186.

2 S. Elstub, O. Escobar, A Typology of Democratic Innovations, Paper delivered at the Political Studies Association's Annual Conference, 10-12 April 2017, Glasgow, https:/www.psa. ac.uk/sites/default/files/conference/papers/2017/A\%20Typology\%20of\%20Democratic\%20 Innovations\%20-\%20Elstub\%20and\%20Escobar\%202017.pdf (5.01.2020); F. Hendriks, Democratic innovation beyond deliberative reflection: the plebiscitary rebound and the advent of action-oriented democracy, «Democratization» 2019, No. 26 (3), pp. 444-464.

3 M.C. Stuttaford, T. Boulle, H.J. Haricharan, Z. Sofayiya, Public and Patient Involvement and the Right to Health: Reflections from England, «Frontiers in Sociology» 2017, 2, art. 5, pp. 1-11.

4 K.S. Quick, M.S. Feldman, Distinguishing Participation and Inclusion, «Journal of Planning Education and Research» 2011, No. 31 (3), pp. 272-290. 
The present article presents empirical research into the implementation of mechanisms of public participation in local municipalities (Pol. "gmina"5) in Poland. The key element of the research essentially illustrates the interdependencies between the tools of participation available (on offer) and the type of municipality. Drawing from the outcomes of quantitative and qualitative research, the author posits the following thesis: with regard to rural municipalities (Pol. "gmina wiejska"), the institutionalisation of the mechanisms of public participation does not change the character of the residents' involvement in public affairs. Public participation in rural municipalities manifests itself in informal initiatives and in the residents' direct contact with the local authorities.

The structure of the present article is as follows: the first part presents the theoretical background of institutionalism, while the subsequent sections focus on the stages of the institutionalisation of the mechanisms of public participation in Poland as well as on the methodological assumptions of the research conducted, and on its ensuing results.

\section{The institutionalisation of the forms of public participation}

The institutionalisation of the tools of participation was a natural consequence of the growing popularity of both participatory democracy and the models of governance based on non-public actors involvement ${ }^{6}$. However, the causes and the course of the processes of institutionalisation were not identical everywhere. In some countries (for instance, the United States of America), the institutionalisation of participatory solutions and their introduction as fully-fledged state institutions were an expression of the recognition of the affects that social movements and grassroots (bottom-up) initiatives ${ }^{7}$ have had on the civil society. In some other countries, such as Latin American states, the top-down process of the institutionalisation of the mechanisms of participation proved to be

5 Throughout the present article, the Polish administrative unit "gmina" is translated as "municipality".

6 G. Smith, Democratic Innovations. Designing Institutions for Citizen Participation, Cambridge University Press New York 2009, pp. 1-2.

7 C. Coglianese, Social Movements, Law, and Society: The Institutionalization of the Environmental Movement, Faculty Scholarship, 2001, Paper 1404, p. 87; http://scholarship.law.upenn.edu/ faculty_scholarship/1404 (12.01.2020). 
a tool of political control, but have also contributed to the mitigation of social and political tensions ${ }^{8}$.

With regard to European countries, formalising participatory practices and incorporating them into local legal orders - at the behest of supranational institutions, such as the European Union - was a fairly popular and universally accepted solution. However, even in this particular case there were visible differences, as the processes of the formalisation and the institutionalisation of the forms of civic involvement were influenced by a series of factors, including: 1) the different traditions of cooperation between citizens and the representatives of the public sector; 2) the strength of non-governmental organisations as a natural powerbase of social mobilisation; 3) social and public activity to date; and 4) legal-organisational determinants enabling (or not) civil participation in political decision making 9 .

In accordance with the principles of new institutionalism, the rationale behind institutions is to serve the implementation of law and order as well as to ensure predictability. They create a formal framework for specific social actors, and by doing so they impose on them the appropriate (universally accepted and adopted) mode of conduct; as a result, they enable interactions between a diversity of actors, thus constituting a platform for communication ${ }^{10}$.

As emphasised by March and Olsen ${ }^{11}$, the advantage of new institutionalism is the universal acceptance of the principles introduced by the

8 R. Abers, From Ideas to Practice: The Partido dos Trabalhadores and Participatory Governance in Brazil, «Latin American Perspectives» 1996, No. 23 (4), p. 50; R. Abers, Practicing Radical Democracy, «disP - The Planning Review» 2001, No. 37(147), pp. 32-38; cf. F. Montambeault, The Politics of Local Participatory Democracy in Latin America: Institutions, Actors, and Interactions, Stanford University Press, Stanford 2016; C. Balderacchi, Problems and contradictions of participatory democracy: lessons from Latin America, «Contemporary Politics» 2016, No. 22 (2), pp. 164-177.

9 S. Russack, Pathways for Citizens to Engage in EU Policymaking, «Policy Insight. Thinking Ahead of Europe» 2018, No. 14 (November); Guidelines for civil participation in political decision making (Adopted by the Committee of Ministers on 27 September 2017 at the $1295^{\text {th }}$ meeting of the Ministers' Deputies, CM(2017)83-final, cf. M. Hooghe, E. Quintelier, Political participation in European countries: The effect of authoritarian rule, corruption, lack of good governance and economic downturn, «Comparative European Politics» 2014, No. 12 (2), pp. 209-232.

10 C. Offe, Designing institutions for East European transitions, Reihe Politikwissenschaft / Institut für Höhere Studien, Abt. Politikwissenschaft, 19, Institut für Höhere Studien (IHS), Wien 1994, p. 9; https://nbn-resolving.org/urn:nbn:de:0168-ssoar-267177 (12.01.2020).

11 J.G. March, J.P. Olsen, Elaborating the "New Institutionalism", [in:] R.E. Goodin (ed.), The Oxford Handbook of Political Science, Oxford University Press, Oxford-New York 2011, pp. 162-163. 
institution, which in turn eliminates accidental and arbitrary activities. Respect for the institution is derived from the methods and circumstances of their creation. As long as the changes are expected by the local community, regarded as desirable, are construed as needed, justified, and in conformity with the law, such institutions are likely to become a long-lasting element of public life ${ }^{12}$.

In comparison with old institutionalism, new institutionalism highlights in a more pronounced way the necessity of reforming the institution; however, the proposed changes must not be imposed on the society against their will ${ }^{13}$. Instead, what should be encouraged is the gradual adjustment of institutions to the changing conditions. Such a process of adaptation ought to constitute the result of social expectations rather than of an arbitrary decision taken by the authorities ${ }^{14}$.

Rational choice institutionalism assumes that the regulations not only define the principles of conduct of particular social actors, but that they also specify the rules that govern the relationship between rational actors to maximise the profits gained ${ }^{15}$. Thus, institutions ought to foster initiatives that act to reduce uncertainty connected with disparate preferences and drives. Such an attitude focuses on the institutional efficiency. Simultaneously, there is an assumption that rational actors not only perceive the specificity of the functioning of the institutions that influence them (as social actors), but that they themselves create and control new institutions in accordance with their own convictions ${ }^{16}$.

V. Lowndes indicates that, according to the founding principles of new institutionalism, institutions "manifest themselves not only in the shape of formal structures and official procedures, but in the form of tacit agreements and conventions as well" 17 . They can also evolve in an unexpected way when actors endeavour to find their bearings in new and unclear circumstances. Striving for stability, they can break, ignore

12 R.E. Goodin, Institution and Their Design, [in:] R.E. Goodin (ed.), The Theory of Institutional Design, Cambridge University Press, New York-Melbourn 1996, p. 22.

13 Ibidem, p. 21.

14 J.G. March, J.P. Olsen, Elaborating..., p. 164. Cf. C. Offe, Institutional Design, [in:] P. Barry Clarke, J. Foweraker (eds.), Encyclopedia of Democratic Thought, Routledge, London-New York 2001, pp. 363-368.

15 V. Lowndes, Instytucjonalizam, [in:] D. Marsh, G. Soker (eds.), Teorie i metody w naukach politycznych, Wydawnictwo Uniwersytetu Jagiellońskiego, Kraków 2006, p. 97.

16 V.A. Schmidt, Give Peace a Chance: Reconciling Four (Not Three) 'New Institutionalisms', Department of International Relations Boston University, Boston, 2006. Paper prepared for presentation for the Annual Meetings of the American Political Science Association (Philadelphia, PA, 31 August - 3 September 2006), p. 2.

17 V. Lowndes, Instytucjonalizm..., p. 99. 
or modify the rules of engagement to be able to accomplish their own goals on their own terms ${ }^{18}$.

\section{The history of institutionalization of public participation mechanisms. An overview of selected regulations}

The process of the institutionalisation of the mechanisms of public participation in Poland commenced in the 1990s as an element of democratization, decentralization and social-economic transition ${ }^{19}$. The implementation of new, after the post-1989 return to multiparty democracy, instruments followed a top-down path and stemmed from the attempt to conform to Western - often alien and incomprehensible - templates or to directives issued by international institutions ${ }^{20}$. The first stage of implementing participatory solutions was more experimental than systemic in nature. The 2000s saw a considerable change with regard to the institutionalisation of the participatory mechanisms in Poland, while the very term 'participation' became consolidated both in its theoretical dimension (as an element of the increasingly more popular concept of governance in Poland) and as a practice of public life 21.

In comparison with Western Europe, the United States of America, and the Anglosphere, the implementation of the mechanisms of public participation in Poland was initiated markedly later, happened over a shorter period of time, and was typified by its top-down character. It was, to a considerable degree, motivated by the necessity to conform to the public governance solutions adopted by the institutions of the European Union ${ }^{22}$. In contrast with the USA, the mechanisms of participation in Poland were not grounded in social movements and bottom-up

18 Ibidem. Also see: V. Lowndes, Management Change in Local Governance, [in:] G. Stoker (ed.), The New Management of British Local Governance, MacMillan Press, London 1999, pp. 24-25.

19 In text, the author draws on the forms of local-level participation developed after 1989. This does not mean, however, that Poland was devoid of a tradition of civic engagement. Still, the post-WWII political situation was not conducive to the involvement of citizens in decisionmaking processes in Poland. For more on the tradition of participation, see J. Bartkowski, Tradycje partycypacji, [in:] A. Olech, Partycypacja publiczna. O uczestnictwie obywateli $w \dot{z} y c i u$ wspólnoty lokalnej, Instytut Spraw Publicznych, Warszawa 2011.

20 Cf. K. Jasiecki, Problemy partycypacji społecznej $w$ Polsce i ich wptyw na politykę publiczna, «Studia z Polityki Publicznej» 2015, No. 3 (7), pp. 107-108.

21 E. Inglot-Brzęk, Znaczenie roli władz samorzadowych $w$ ksztattowaniu partycypacji obywatelskiej, «Nierówności Społeczne a Wzrost Gospodarczy» 2017, No. 50 (2), p. 335.

22 European Governance. A White Paper, Commission of the European Countries, Brussels, 25 July 2001, COM(2001), 428 final. Cf. T.A. Börzel, Y. Pamuk, A. Stahn, Good Governance in the 
initiatives ${ }^{23}$. They were not given enough time to mature as was the case of Western European countries, where institutionalisation started already in the mid-twentieth century. In different parts of the continent, the processes of the institutionalisation of participatory mechanisms unfolded in a variety of ways, and were informed by disparate motives. For instance, the implementation of the participatory solutions in France was considered 'a remedy' for the citizens' disappointment with representative democracy ${ }^{24}$. The institutionalisation of the instruments of participation constituted also a consequence of 'democratic experiments' or 'innovations', especially in countries without a long-standing tradition of civic engagement, such as Spain ${ }^{25}$, which resulted in the given local context having a marked effect their diversification and efficiency ${ }^{26}$. In Germany, the institutionalisation was a result of the activities undertaken by protest groups and policies adopted by local authorities ${ }^{27}$. The implementation of instruments of local-level participation was supposed not only to galvanise citizens into action, but - due to a wide range of

European Union, Berlin Working Paper on European Integration No. 7, Freie Universität, Berlin 2008.

23 See C. Pateman, Participatory Democracy Revisited, «Perspectives on Politics» 2012, No. 10 (1), pp. 7-19; A. Fung, E.O. Wright, Deepening Democracy: Innovations in Empowered Participatory Governance, «Politics \& Society» 2001, No. 29(1), pp. 5-41; J. Landry, L. Angeles, Institutionalizing Participation in Municipal Policy Development: Preliminary Lessons from a Start-Up Process in Plateau-Mont-Royal, «Canadian Journal of Urban Research» No. 20 (1), pp. 105-130.

24 A. Mazeaud, M. Nonjon, The Participatory Democracy Market in France: Between Standarization and Fragmentation, [in:] L. Bherer, M. Gauthier, L. Simard (eds.), The Professionalization of Public Participation, Routledge, New York 2017. Also see: C. Kamaté, Public Participation in the Debate on Industrial Risk in France: A Success Story?, [in:] M. Bourrier, C. Bieder (eds.), Risk Communication for the Future. Towards Smart Risk Governance and Safety Management, Springer Open, Cham 2018, p. 19.

25 J. Font, C. Naverro, Personal Experience and the Evaluation of Participatory Instruments in Spanish Cities, «Public Administration» 2013, No. 19 (3), pp. 616-631.

26 C. Navarro, J. Font, The Biased Inclusiveness of Local Democratic Innovations: Vehicles or Obstacles for Political Equality?, [in:] B. Geissel, M. Joas (eds.), Participatory Democratic Innovations in Europe: Improving the Quality of Democracy?, Verlag Barbara Budrich, Opladen; Berlin; Toronto 2013, pp. 98-99.

27 R. Schröter, Quo Vadis - Citizen Participation in Germany, «International Journal of Deliberative Mechanisms in Science» 2016, No. 4(1), pp. 65-81; S. Royo, A. Yetano, B. Acerete, Citizen Participation in German and Spanish Local Governments: A Comparative Study, «International Journal of Public Administration» 2011, No. 34 (3), pp. 139-150; K. Kern, C. Koll, M. Schophaus, Local Agenda 21 in Germany: An inter- and intranational comparison, WZB Discussion Paper, No. SP IV 2004-104, Wissenschaftszentrum Berlin für Sozialforschung (WZB), Berlin 2004. 
public services performed at the local level - to curtail public spending as well 28 .

The beginning of the institutionalisation of modern mechanisms of public participation in Poland can be justifiably connected with the amendments to the Act on Local-Self-government (in 2001 and 2013), which included the introduction of youth councils and senior councils ${ }^{29}$. Both types of bodies previously functioned despite the lack of direct references in legal acts ${ }^{30}$.

Subsequently, other important changes with regard to the range of the institutionalisation of participatory mechanisms were introduced by means of the Public Benefit Activities and Volunteer Work Act ${ }^{31}$. In terms of the tools of civic engagement, the statute regulated the issues of public consultations and the participation of non-state entities in public service delivery, as well as introduced councils of public benefit activities $^{32}$. While in 2010 an Amendment to the Act resulted in the introduction of the instrument of the local initiative, a significant if still under-implemented instrument of participation in Poland ${ }^{33}$.

28 B. Geissel, How to Improve the Quality of Democracy? Experiences with Participatory Innovations at the Local Level in Germany, «German Politics and Society» 2009, No. 27 (4), p. 58.

29 Art. 5b, The 11 April 2001 Act Amending the Acts on Local Self-Government, on Powiat Self-Government, on Province Government, on Province Government Administration, and other Acts, Dz.U. 2001, No. 45, item 497, No. 89, item 971; art. 5c, [The 11 October 2013 Act on Amending the Act on Local Self-Government], Dz.U. 2013, item 1318.

30 E.g. M. Brol, Młodzieżowa rada gminy jako przykład uczestnictwa młodzieży w życiu społeczno-politycznym, «Studia Politicae Universitatis Silesiensis» 2013, No. 10, pp. 30-52; https://www. journals.us.edu.pl/index.php/SPUS/article/view/6351 (14.01.2020); A. Bilnicka, A. Cioch, B. Kazior, Rady seniorów. (Milowy) Krok po kroku, Fundacja Miejsc i Ludzi Aktywnych, Kraków 2018.

31 Ustawa z dnia 24 kwietnia 2003 r. o działalności pożytku publicznego i o wolontariacie [The 24 April 2003 Act on the Public Benefit Activities and Volunteer Work], Dz.U. 2003, No. 96, item 873 with further amendments.

32 Councils of Public Benefit Activities - collegial bodies that serve the opinion-giving and advisory function for public authorities. As such, they constitute representatives of NGOs. The tasks performed by the councils include giving opinion on the documents and plans prepared by the authorities with regard to the social sector. The institution of the Council of Public Benefit Activities was introduced into the Polish legal order with the passing of the Act on the Public Benefit Activities and Volunteer Work in 2003. Initially, the councils were not obligatory. It was possible to establish them at all self-governmental levels (i.e. gmina - municipality, powiat - district, województwo - region). Since 2015, establishing such bodies has been obligatory at the municipality and district levels whenever any NGO operating on the territory of a given administrative unit puts forward a specific motion.

33 Chapter 2a, The 22 January 2010 Act Amending the Act on the Public Benefit Activities and Volunteer Work and other Acts, Dz.U. 2010, No. 28, item 146. 
The idea of the local initiative consisted of cooperation of (informal) social groups and the (local) authorities of a given municipality with a view to delivering public services. The role of the local community was not to be limited to merely initiating ideas, and singling out areas for the authorities to intervene and duly tackle, but to enable participation in the delivery of public services, and to allow the said community to make a considerable contribution while doing so, be it financial or inkind contribution ${ }^{34}$. The local initiative was designed as an instrument for local communities that were unable to create on their own stable legal forms of civic engagement (associations, foundations) due to their formalized character. Eventually, however, the structure of the local initiative as a participatory tool proved too complex to become a widely implemented mechanism ${ }^{35}$.

The 2009 Act on the Solectwo Fund ${ }^{36}$ marked a crucial step in the process of the institutionalisation of participatory mechanisms. Its governing principle was the activation of rural communities and the inclusion of residents into the decision-making process with regard to their surroundings. Thanks to its financial character, the instrument facilitates real-life, palpable activities. In contrast with the local initiative, the fund is popular in Poland and is implemented by almost three-fourths of municipalities where Solectwo exists ${ }^{37}$. In short, one could state that the fund acts as 'a participatory budget' for rural communities, who in turn are at liberty to decide on the allocation of financial means provided for in the budget of their municipality. The Solectwo fund is a participatory tool that is also appealing to local authorities, as the legislator provided for the reimbursement of a substantial share of the expenses (20-40\%) incurred by each municipality in the course of its implementation ${ }^{38}$.

34 A. Kołomycew, Możliwość wykorzystania inicjatywy lokalnej w procesie wspótrządzenia $w$ jednostkach terytorialnych, [in:] K. Kuć-Czajkowska, M. Sidor (eds.), Miasta: spoteczne aspekty funkcjonowania, Wydawnictwo UMCS, Lublin 2014.

35 NIK, Realizacja zadan publicznych $w$ ramach inicjatywy lokalnej. Informacja o wynikach kontroli, KAP.430.017.2018 Nr ewid. 177/2018/P/18/004/KAP, Warszawa 2019.

36 The 21 January 2014 Act on Solectwo Fund, Dz.U. 2014, item 301, is currently in force.

37 Sołectwo is an auxiliary unit of municipality. The scope of activities undertaken by a given sołectwo is assigned by the municipal council on the territory of which said solectwo is established. According to the research carried out by the Ministry of the Interior and Administration (MSWiA) and Central Statistical Office (GUS), in 2017 sołectwo functioned in 2174 municipalities out of 2478. See: MSWiA, "Fundusz sołecki", https://www.gov. $\mathrm{pl} /$ web/mswia/fundusz-solecki (3.01.2020). Also see: A. Ptak, Lokalna społeczność $w$ procesie tworzenia funduszu soteckiego, «Studia Regionalne i Lokalne» 2015, No. 1 (59), pp. 138-153.

38 A. Ptak, Lokalna..., p. 140. 
2018 saw a series of significant changes in the process of the institutionalisation of participatory mechanisms with the adoption of the statute aiming, "to increase the participation of citizens in the procedures of electing, functioning and controlling of select public bodies" 39 . The key amendments included: the introduction of obligatory participatory budgeting in cities with county status ${ }^{40}$ (with regard to other territorial units, participatory budgeting remains an optional instrument), the further specification of the citizens' local and regional level legislative initiative $^{41}$, as well as the introduction of an obligatory debate on the state of the municipality ${ }^{42}$ (preceded by an annual report on the state of the municipality prepared by its authorities), which would allow for the active participation of citizens ${ }^{43}$.

One ought to state that, apart from the aforementioned regulations, the obligation or recommendations to implement participatory mechanisms, such as seeking advice of opinion-giving bodies on the part of authorities or conducting public consultations, are included in a series of specific statutes regarding among others the issues of revitalisation ${ }^{44}$ (appointing a revitalisation committee), spatial planning 45 or other issues pertaining to the functioning of local government units ${ }^{46}$. Due

39 The 11 January 2018 Act on Amending Select Acts with a View to Increasing the Participation of Citizens in the Process of Electing, Functioning, and Controlling of Some Public Organs, Dz.U. 2018, item 130.

40 A city with powiat status is a local governmental unit in Poland, which de facto constitutes a municipality, but also performs the tasks allocated to county (Pol. powiat). Such a solution has been introduced into the legislation due to the size of the units and the necessity to expand the scope of their tasks. At present, there are altogether 66 cities with powiat status in Poland.

41 E. Zielińska, D. Kraszewski, Narzędzia partycypacji lokalnej $w$ Polsce w latach 2014-2017. Konsultacje spoteczne, inicjatywa lokalna, inicjatywa uchwałodawcza, Fundacja im. Stefana Batorego, Warszawa 2019, p. 18.

42 The solution provided for in the legislation available is not typified by the spirit of a universal public debate; nor does it resemble any mechanism of deliberative democracy. An opportunity for citizens to voice their opinion during a debate is permissible only if an appropriate motion - supported by a statutory number of residents of a given municipality - has been tabled for discussion.

43 Dz.U. 2018, item 130. Also see: M. Pszczyński, P. Sobczyk, Nowelizacja przepisów samorzadowych $i$ wyborczych - aspekty prawne $i$ praktyczne istotne dla jednostek samorzadu gminnego, «Ekspertyzy i Opracowania» 2018, No. 38, Narodowy Instytut Samorządu Terytorialnego.

44 The 9 October 2015 Act on Revitalisation, Dz.U. 2019, items 730, 1696, 2020.

45 The 27 March 2003 Act on Planning and Land Development, Dz.U. 2003, No. 80, item 717.

46 S. Pawłowski, Konsultacje obligatoryjne i fakultatywne $w$ ustawie o planowaniu $i$ zagospodarowaniu przestrzennym a zakres uspołecznienia procesów planowania przestrzennego, «Ruch Prawniczy, Ekonomiczny i Socjologiczny» 2015, LXXVII - Vol. 1, pp. 203-217. Cf. M. Wenclik, Prawne 
to the number of regulations available, the present text only refers to selected legal solutions.

\section{Research methodology}

The purpose of the research was to identify the differences in the scope of the implementation of institutionalised forms of public participation in municipalities. The quantitative research was conducted in 2017 on a representative sample of 525 municipalities, which represented three distinct types, i.e. urban ${ }^{47}$, urban-rural, and rural. A questionnaire (CATI) that comprised of 24 questions (both open-ended and closedended) and four sociodemographic questions was sent to representatives of local self-governments and regional civil servants.

Having analysed the answers to the aforementioned questionnaire, the author created an original participation ranking, which served as the foundation for the further selection of municipalities with a view to conducting qualitative research. The selection (short-list) was purposedriven (deliberate), as the rationale behind the research was to choose municipalities belonging to each of three types under discussion, while including also extreme municipalities, i.e. ones that scored the highest and the lowest points. ${ }^{48}$ Eventually, 12 municipalities were singled out, and 44 in-depth interviews were conducted altogether in 2018 and in 2019. The interviews followed a pre-prepared scenario, which were modified depending on the particular respondents, i.e. municipal authorities (executive bodies, councillors), local leaders (including village leaders, pol. soltys), the representatives of NGOs, and the residents of municipalities under discussion, who availed themselves of participatory mechanisms. All the interviews conducted were transcribed and subsequently encoded using QDA Miner Lite.

i pozaprawne uwarunkowania konsultacji społecznych, Państwowa Wyższa Szkoła Informatyki

i Przedsiębiorczości w Łomży, Łomża 2016, pp. 81-99.

47 Urban municipalities comprised also cities with county status, i.e. municipalities typified by their special status. However, due to the topics discussed in the present article, the author jointly analyses these two types of municipalities.

48 The ranking of participation was created on the basis of allocation of specific points to particular survey questions. In the ranking under consideration, the maximum score is 54 , while the minimum score is 2 . 


\section{The scope of the implementation of participatory instruments in Polish municipalities: research outcomes}

Despite the ever-growing catalogue of participatory instruments and the increasing popularity of democratic experiments, the municipalities under discussion participate in fairly typical and hardly refined forms of civic engagement. One of the most common, and simultaneously one of the most controversial, with regard to (arguable) the lack of effects is the mechanism of local participation public consultation ${ }^{49}$. In addition, a wide catalogue of participation instruments is available at the municipal level including different types of collegial or deliberative bodies (Table 1).

Table 1. The implementation of participatory mechanisms in municipalities

\begin{tabular}{|c|c|c|c|c|}
\hline \multirow{2}{*}{\multicolumn{2}{|c|}{$\begin{array}{l}\text { Applicable forms of citizens' participation - civic } \\
\text { engagement (other than public consultations): }\end{array}$}} & \multicolumn{3}{|c|}{ Type of municipality: } \\
\hline & & \multirow{2}{*}{$\begin{array}{c}\text { urban } \\
18 \\
\end{array}$} & \multirow{2}{*}{$\begin{array}{c}\text { urban-rural } \\
29 \\
\end{array}$} & \multirow{2}{*}{$\begin{array}{c}\text { rural } \\
59 \\
\end{array}$} \\
\hline task-specific / problem-specific councils & $\mathrm{n}$ & & & \\
\hline $\begin{array}{l}\text { (appointed if need be / on an emergency } \\
\text { basis) }\end{array}$ & $\%$ & $40.0 \%$ & $25.9 \%$ & $16.0 \%$ \\
\hline \multirow{2}{*}{$\begin{array}{l}\text { permanent advisory and opinion-giving } \\
\text { councils / teams / committees }\end{array}$} & $\mathrm{n}$ & 16 & 22 & 42 \\
\hline & $\%$ & $35.6 \%$ & $19.6 \%$ & $11.4 \%$ \\
\hline \multirow{2}{*}{ youth municipal council } & $\mathrm{n}$ & 26 & 21 & 19 \\
\hline & $\%$ & $57.8 \%$ & $18.8 \%$ & $5.2 \%$ \\
\hline \multirow{2}{*}{ participatory budgeting council / team } & $\mathrm{n}$ & 12 & 20 & 17 \\
\hline & $\%$ & $26.7 \%$ & $17.9 \%$ & $4.6 \%$ \\
\hline \multirow{2}{*}{ senior council } & $\mathrm{n}$ & 18 & 16 & 11 \\
\hline & $\%$ & $40.0 \%$ & $14.3 \%$ & $3.0 \%$ \\
\hline \multirow{2}{*}{ other forms } & $\mathrm{n}$ & 0 & 4 & 10 \\
\hline & $\%$ & $0.0 \%$ & $3.6 \%$ & $2.7 \%$ \\
\hline \multirow{2}{*}{$\begin{array}{l}\text { new techniques of participation } \\
\text { (e.g. open space, citizens' cafeteria, } \\
\text { deliberative opinion poll, citizens' walk, } \\
\text { research opinion poll, public forum debate, } \\
\text { social dialogue commission) }\end{array}$} & $\mathrm{n}$ & 9 & 7 & 11 \\
\hline & $\%$ & $20 \%$ & $6.3 \%$ & $3 \%$ \\
\hline \multirow{2}{*}{$\begin{array}{l}\text { lack of other forms of citizens' participation } \\
\text { (civic engagement) }\end{array}$} & $\mathrm{n}$ & 7 & 43 & 236 \\
\hline & $\%$ & $15.6 \%$ & $38.4 \%$ & $64.1 \%$ \\
\hline altogether & $\mathrm{n}$ & 45 & 112 & 368 \\
\hline
\end{tabular}

Source: research on the basis of the analysis of interview questionnaires.

49 A large part of the research concerned public consultations. Nevertheless, at this point, the author presents only those forms of participation that have been institutionalized in Poland in recent years and regulated by national statutes. 
The most marked differences (between rural and urban municipalities) are predominantly with regard to the permanency of the solutions, such as advisory and opinion-giving councils or committees, which - although it is difficult to ascertain their real-life influence on the decisions - provide at least a formal representation of different social groups in the decision-making process. Permanent participatory mechanisms require not only the constant activity of their participants, but also knowledge (including professional expertise) and information constituting the foundation of the functioning of an advisory body, which are easier accessible in urban municipalities ${ }^{50}$. Other factors affecting the greater popularity of permanent (collegiate) forms of participation in urban municipalities also include the availability of experts, the lifestyle of residents and their mentality, which affects their involvement in public issues ${ }^{51}$.

On the basis of the results of the quantitative results presented above, one cannot, however, unambiguously assert that the involvement of the citizens of rural municipalities in public affairs is weaker than the inhabitants of urban areas. What the interviews reveal is that public engagement in rural municipalities manifests itself primarily in nonformalised way, most frequently in direct contact between members of a local community and municipal authorities and regional civil servants. The assumption is corroborated by the following statement of one of the mayors:

(...) We meet these people on a daily basis - we talk together, we know each other. There are, you know, 9500 inhabitants altogether so one really knows everyone by sight... (...) But sometimes I just prefer to sit down with people and talk. I am going somewhere or riding my bike and suddenly somebody stops me - I have a number of friends, yes, I meet them. $(\mathrm{O} / \mathrm{II} / \mathrm{W})^{52}$.

The preference for less formalised participatory solutions in rural municipalities is reflected by the answers to the question concerning the

50 J. Font, S. Pasadas, J.L. Fernández-Martínez, Participatory Motivations in Advisory Councils: Exploring Different Reasons to Participate, «Representation» 2019, DOI: 10.1080/00344893.2019.1643774.

51 Cf. M. Turcotte, Social engagement and civic participation: Are rural and small-town populations really at an advantage?, «Rural and Small Town Canada Analysis Bulletin Catalogue» 2005, No. 6(4) 21-006-XIE V, pp. 1-24. Also see: P. Sadura, K. Murawska, Z. Włodarczyk, Wieś w Polsce. Diagnoza i prognoza. Raport z badania, Fundacja Wspomagania Wsi, Warszawa 2017.

52 The individual symbols in the interview code mean: region in which the municipality is located, interview number in the given municipality, respondent function (e.g. W - mayor, $\mathrm{U}$ - local administration staff, $\mathrm{O}-\mathrm{NGOs)}$. 
forms of delivery of public tasks (services) with participation of citizens (Table 2).

Table 2. Select forms of the delivery of public tasks (services) with citizens' participation $^{53}$

\begin{tabular}{|l|c|c|c|c|}
\hline \multirow{2}{*}{$\begin{array}{l}\text { Select forms of citizens' participation in the } \\
\text { processes of the delivery of public tasks (services) }\end{array}$} & \multicolumn{4}{|c|}{ Type of municipality: } \\
\cline { 2 - 6 } & urban & urban-rural & rural \\
\hline \multirow{2}{*}{ tasks delivered as part of the solecki fund } & $\mathrm{n}$ & 10 & 86 & 261 \\
\cline { 2 - 6 } & $\%$ & $22.2 \%$ & $76.8 \%$ & $70.9 \%$ \\
\hline \multirow{2}{*}{$\begin{array}{l}\text { tasks delivered as part of participatory } \\
\text { budgeting }\end{array}$} & $\mathrm{n}$ & 28 & 42 & 71 \\
\cline { 2 - 6 } & $\%$ & $62.2 \%$ & $37.5 \%$ & $19.3 \%$ \\
\hline \multirow{2}{*}{ tasks delivered within the local initiative } & $\mathrm{n}$ & 8 & 12 & 41 \\
\cline { 2 - 6 } & $\%$ & $17.8 \%$ & $10.7 \%$ & $11.1 \%$ \\
\hline altogether & $\mathrm{n}$ & 45 & 112 & 368 \\
\hline
\end{tabular}

Source: research on the basis of the analysis of interview questionnaires.

The above juxtaposition shows that in rural municipalities the solecki fund constitutes the most attractive tool of participation. Its popularity stems from the relatively simple form (a motion, once tabled, is passed during a village meeting and submitted to the municipality's executive body), and the encouragement to implement it on the part of the municipal authorities that are compensated a significant share of the expenses incurred in the process of the tool's introduction. As a result, the solecki fund enjoys the status of being a widely known and increasingly popular participatory mechanism.

However, in the course of the qualitative research practices likely to weaken the potential of the solecki fund as a participatory mechanism have also been identified. Such a situation occurs when a local community is at a loss how to use the allocated funds, as the basic needs (e.g. infrastructure) have already been satisfied, while social integration or cultural activities can be justifiably financed through sources specifi-

53 In the interview questionnaire, the respondents were posed questions concerning different forms of delivery of public tasks (services) with citizens' participation. Table No. 2 includes only select forms of delivery, excluding such solutions as entrusting non-state entities with public tasks (services) or creating different cross-sectoral partnerships. Due to complexity of related subjects, these solutions demand further scholarly attention that the present article, given its primary scope, cannot provide. As the respondents were free to select multiple answers, they do not add up to $100 \%$. 
cally created for the sake of rural municipalities (e.g. European Funds). If this is the case (as well as in less affluent municipalities), then the initiative is taken over by the municipal authorities, who attempt to navigate the solecki fund (through the intermediary of local leaders) and to assign particular tasks to this specific participatory instrument. In practice, what is at stake is not so much the curtailing of participation in rural municipalities, but rather the rationalization of expenses. The following statement by mayor of one of the rural municipalities under discussion provides a fitting example of the above:

People assume that the solecki fund will fix it all once and for all. It won't - this is just what people wrongly assume (...) This is not only a dilution of the budget as such, but in the case of my municipality, which is in debt, which is not rich enough, then this budget is fairly small, and material expenses - investments are also small. So this is really like heading for a fall - reaching a crisis by means of the solecki fund. (M/I/W).

An instrument similar to the solecki fund, participatory budgeting has enjoyed unprecedented popularity in recent years, especially in urban and urban-rural municipalities in Poland (Table 2) ${ }^{54}$. The tool has also been the subject of numerous publications and reports, systematically evaluating its implementation in Polish cities ${ }^{55}$. With regard to the municipalities under discussion, it was introduced in a top-down fashion, initiated by the authorities, and was - as a result - perceived more as a means of self-promotion of municipalities and the administration than as an expression of willingness to include the local community in the allocation and management of the unit's budget. Undoubtedly, interest in participatory budgeting - especially during the initial rounds (on condition that the residents were properly prepared to embrace the mechanism) - was considerable, as highlighted by the respondents during interviews. In comparison with the solecki fund, this solution remains, however, far more time-consuming and formalised. In consequence, it was not uncommon for the idea submitted as part of participatory bud-

54 Although participatory budgeting is implemented in rural municipalities, it enjoys an experimental status there rather than functioning as a universal, commonly used mechanism. See more: K. Leśniewska-Napierała, Budżet obywatelski jako nowy instrument partycypacji społecznej na obszarach wiejskich w Polsce, «Studia Obszarów Wiejskich» 2019, No. 53, pp. 77-93.

55 D. Rybińska, Instytucja budżetu obywatelskiego jako narzędzia rozwoju samorządu lokalnego, «Finanse i Prawo Finansowe» 2018, No. 1 (17), pp. 49-65; B. Pytlik, Budżet partycypacyjny $w$ Polsce. Ewolucja i dylematy, «Studia z Polityki Publicznej» 2017, No. 1, pp. 103-122; Miasto 2077, Raport. Budżet obywatelski w polskich miastach, March 2019, http://www.miasto2077.pl/ wp-content/uploads/2019/03/Raport-Budz\%CC\%87ety-Obywatelskie-w-polskich-miastach. pdf (10.01.2020). 
geting not to be a bottom-up initiative of the residents, but a product of a NGOs that - due to their experience - were capable of complying with all the formalities involved ${ }^{56}$. Not unlike the case of the solecki fund, the research elicited situations that to an extent undermined the idea of participatory budgeting, i.e. public tasks (services) that are submitted and funded in the subsequent editions of the programme. In one of the municipalities under discussion, representatives of NGOs - as natural persons - first submitted proposals of activities to be financed through participatory budgeting, and then - once the task had been selected - they had to take part (already as an NGO) in a competition to contract this public task. An example of such a practice is the following statement made by an initiator of an activity within the participatory budgeting, who also happens to be a member of a local non-governmental organization:

(...) we submit our ideas as natural persons, yes, I myself as $X^{57}$, my friend as $\mathrm{Y}$ and so on, and the third person submits the third project. And subsequently there is a competition for the delivery of projects that have been approved of (...) Nobody has ever entered [the competition - author's note]. This I think stems from the fact that the classes require specialist knowledge, and that we include there stringent criteria and put excessive demands on specialists and require mandatory long-standing experience, professional certificates... (L/IX/O1).

Although the aforementioned practice contradicts the very notion of participatory budgeting, it ultimately enables the delivery of tasks needed by the local community (e.g. assistance to children with disabilities and their families), which is evidenced by the fact that the projects submitted to participatory budgeting receive enough votes to secure their funding. Thus, it is difficult to unequivocally criticise such a practice, as it constitutes a means of delivering tasks that are crucial to

56 Due to non-existence of uniform regulations pertaining to participatory budgeting, the scope of eligible entities was regulated locally, i.e. in each unit implementing this particular mechanism. The municipalities under consideration introduced certain limitations that excluded certain bodies, e.g. schools or NGOs, from submitting applications. These regulations were justified as follows: the existing procedures were dominated by some bodies, which in turn curtailed the opportunities for other, including non-formalised, groups of citizens (the argument concerning exclusion of NGOs) and groups characterised by a lesser activation potential (the argument concerning schools with considerable leverage on the pupils' parents / guardians).

57 The respondent provided both names and surnames. In order to guarantee anonymity of the people interviewed, surnames were redacted in the course of the transcription of the interviews. 
the local community and that - due to economic constraints, i.e. limited municipal budget - could not have been funded otherwise.

The last of the participatory instruments, whose (excessive) institutionalisation has brought about the opposite effect from what was intended, is 'local initiative'. The overly complex formal requirements of this mechanism means that is it rarely implemented. At best, it is implemented informally, i.e. the rationale behind this instrument is duly preserved (joint activities undertaken by the local authorities and the residents), but the formal regulations prescribed by statute are ignored. Table 2 provides ample evidence that local initiative in the municipalities under discussion was altogether rarely implemented ${ }^{58}$. The reasons for not making use of the instrument, as stated by the respondents, for example representatives of the local community, included overly complicated regulations (the necessity to adopt an appropriate resolution by the municipal council) and unfamiliarity with the rules of task delivery.

Furthermore, reluctance to make use of the instrument may arise from the obligation imposed on the local community not only to submit ideas but to participate in their delivery as well (which entails additional work or financial input). To the respondents, however, citizens' involvement is primarily limited to the stage of generating ideas, and does not encompass the production / delivery stage:

No, it is not that they supervise [the delivery of tasks - author's note]. They [residents of a given municipality - author's note] rather have an idea. But later on, delivery is assigned to us [local administration - author's note]. (L/ $\mathrm{IX} / \mathrm{U})$.

The main reason for not making use of the local initiative seems to be the excessive formalization of this instrument. The main reason thus is not lack of willingness to act collectively on the part of the members of local communities or municipal authorities. The interviews conducted clearly prove that such a form of cooperation did indeed take place in the municipalities under consideration, yielding results beneficial to both parties. However, taking collective action with recourse to the local initiative as an instrument of participation proved problematic. Although, in accordance with the rationale behind the introduction of the local initiative, there was expected an improvement with regard to the cooperation within territorial units (i.e. cooperation between the authorities

58 E. Zielińska, D. Kraszewski, Narzędzia partycypacji lokalnej $w$ Polsce w latach 2014-2017. Konsultacje społeczne, inicjatywa lokalna, inicjatywa uchwatodawcza, Fundacja im. Stefana Batorego, Warszawa 2019, s. 18. Cf. NIK 2019. 
and other local stakeholders), the scale of formalities connected with the execution of tasks (delivery of services) as part of the local initiative has in effect discouraged the local communities from implementing the mechanism widely. The following statement made by a representative of one of local associations and a councillor provides a fitting example:

It was executed in this way [a local initiative was carried out - author's note], when, for example, building materials to erect an arbour were bought with recourse to the solecki fund. So this is what the local community simply does. So there is local initiative ... (O/II/R1).

The statement above shows that local initiative is understood as bottom-up activities undertaken jointly by the local community and the municipal authorities. The basis of the residents' involvement is provided by a specific need, which galvanises the inhabitants into action that can be carried out without any formalised instruments ${ }^{59}$.

\section{Conclusion}

The institutionalisation of participatory mechanisms primarily contribution is to guarantee citizens an opportunity to take part in public life. As a process, it is an expression of the empowerment of citizens, and provides them with - at least formally - an avenue to influence the public sphere. However, the adoption of legal regulations and subsequent imposition by the legislator - as some cases attest - of an obligation to implement specific mechanisms on local authorities do not always result in an increase in civic engagement.

The process of the institutionalisation of participatory mechanisms calls for acknowledging the social context, the potential of the local community, the experiences of cooperation between authorities and citizens, and the needs of particular local actors. In some municipalities, a given mechanism may bear fruit, while in others it may entirely fail to win favour with the residents and/or authorities, whose role - as initiators of particular mechanisms - is of paramount importance. Taking into consideration the specificity of municipalities, such as their type, is also crucial. With regard to the process of the institutionalisation of participatory mechanisms, the legislator did not take into consideration

59 Cf. L. Robinson, J. Phillips (et al.), What Motivates Citizens to Participate? Report, The Digital Public Squere, Munt School of Global Affairs, The University of Toronto, Toronto 2016, https:// digitalpublicsquare.com/media/DPS-Motivational-Reportv9.pdf (10.01.2020). 
the specificity of territorial units. Designing the mechanisms of civic engagement, the legislator failed to account for a diversity of conditions, including among others the specificity of social orders, political culture, and the nature of cooperation between the public authorities and the local community. These can, to a considerable degree, determine the implementation of particular participatory mechanisms (or not making use of them if they are not obligatory), modes of their implementation, and the results thereof.

Despite ongoing social changes, there are noticeable differences between the specific nature of the engagement of rural communities and the residents of urban areas. Rural municipalities still abound in traditional, frequently non-formal, manifestations of residents' involvement. The relationship between its residents and the municipal authorities follow an analogous pattern. The fact that rural municipalities are less populated than cities makes the citizens' interaction with both the authorities and the local administration a lot more direct. As the research conducted corroborates, the normative institutionalisation of participatory mechanisms results in over-regulation, which causes obligatory mechanisms (e.g. public consultations) to be treated perfunctorily, while optional ones are either customised to satisfy the needs and expectations of municipal residents (e.g. informal local initiative) or have been ignored, and have never been implemented. However, institutionalisation does not translate into the residents' interest in the matters related to the municipality they inhabit, as - in the case of less populated municipalities - it all comes down to direct contact and informal meetings with the local authorities. Difficult as gauging the efficiency of informal participation may be, it is of key importance as far as rural municipalities are concerned.

Due to clear research questions, a solid theoretical background linked with empirical research, the paper generates new and relevant knowledge. I strongly recommend it for publication. The conclusion, however, could have gone a but deeper also thematised the impact of the research on new institutionalism.

\section{Bibliography}

R. Abers, From Ideas to Practice: The Partido dos Trabalhadores and Participatory Governance in Brazil, «Latin American Perspectives» 1996, No. 23 (4).

R. Abers, Practicing Radical Democracy, «disP - The Planning Review» 2001, No. 37 (147). 
C. Balderacchi, Problems and contradictions of participatory democracy: lessons from Latin America, «Contemporary Politics» 2016, No. 22 (2).

J. Bartkowski, Tradycje partycypacji, [in:] A. Olech, Partycypacja publiczna. O uczestnictwie obywateli w życiu wspólnoty lokalnej, Instytut Spraw Publicznych, Warszawa 2011.

T.A. Börzel, Y. Pamuk, A. Stahn, Good Governance in the European Union, Berlin Working Paper on European Integration No. 7, Freie Universität, Berlin 2008.

M. Brol, Młodzieżowa rada gminy jako przykład uczestnictwa młodzieży $w$ życiu społeczno-politycznym, «Studia Politicae Universitatis Silesiensis» 2013, No. 10, https:/www.journals. us.edu.pl/index.php/SPUS/article/view/6351 (14.01.2020).

C. Coglianese, Social Movements, Law, and Society: The Institutionalization of the Environmental Movement, Faculty Scholarship, 2001, Paper 1404, http://scholarship.law.upenn.edu/ faculty_scholarship/1404 (12.01.2020).

O. Elstub, O. Escobar, A Typology of Democratic Innovations, Paper delivered at the Political Studies Association's Annual Conference, 10-12 April 2017, Glasgow, https://www. psa.ac.uk/sites/default/files/conference/papers/2017/A\%20Typology\%20of\%20Democratic\%20Innovations\%20-\%20Elstub\%20and\%20Escobar\%202017.pdf (5.01.2020).

J. Font, C. Naverro, Personal Experience and the Evaluation of Participatory Instruments in Spanish Cities, «Public Administration» 2013, No. 19(3).

J. Font, S. Pasadas, J.L. Fernández-Martínez, Participatory Motivations in Advisory Councils: Exploring Different Reasons to Participate, «Representation» 2019, DOI: 10.1080/00344893.2019.1643774.

A. Fung, E.O. Wright, Deepening Democracy: Innovations in Empowered Participatory Governance, «Politics \& Society» 2001, No. 29 (1).

B. Geissel, How to Improve the Quality of Democracy? Experiences with Participatory Innovations at the Local Level in Germany, «German Politics and Society» 2009, No. 27 (4).

R.E. Goodin, Institution and Their Design, [in:] R.E. Goodin (ed.), The Theory of Institutional Design, Cambridge University Press, New York-Melbourn 1996.

F. Hendriks, Democratic innovation beyond deliberative reflection: the plebiscitary rebound and the advent of action-oriented democracy, «Democratization» 2019, No. 26 (3).

M. Hooghe, E. Quintelier, Political participation in European countries: The effect of authoritarian rule, corruption, lack of good governance and economic downturn, "Comparative European Politics» 2014, no. 12 (2).

E. Inglot-Brzęk, Znaczenie roli władz samorzadowych $w$ kształtowaniu partycypacji obywatelskiej, «Nierówności Społeczne a Wzrost Gospodarczy» 2017, No. 50 (2).

K. Jasiecki, Problemy partycypacji społecznej $w$ Polsce $i$ ich wptyw na polityke publiczna, «Studia z Polityki Publicznej» 2015, No. 3(7).

C. Kamaté, Public Participation in the Debate on Industrial Risk in France: A Success Story?, [in:] M. Bourrier, C. Bieder (eds.), Risk Communication for the Future. Towards Smart Risk Governance and Safety Management, Springer Open, Cham 2018.

K. Kern, C. Koll, M. Schophaus, Local Agenda 21 in Germany: An inter- and intranational comparison, WZB Discussion Paper, No. SP IV 2004-104, Wissenschaftszentrum Berlin für Sozialforschung (WZB), Berlin 2004.

A. Kołomycew, Możliwość wykorzystania inicjatywy lokalnej w procesie wspótrzadzenia w jednostkach terytorialnych, [in:] K. Kuć-Czajkowska, M. Sidor (eds.), Miasta: spoteczne aspekty funkcjonowania, Wydawnictwo UMCS, Lublin 2014.

J. Landry, L. Angeles, Institutionalizing Participation in Municipal Policy Development: Preliminary Lessons from a Start-Up Process in Plateau-Mont-Royal", «Canadian Journal of Urban Research» 2011, No. 20 (1). 
J. Landry, L. Angeles, Institutionalizing Participation in Municipal Policy Development: Preliminary Lessons from a Start-Up Process in Plateau-Mont-Royal, "Canadian Public Policy» 2011, No. 20 (1).

K. Leśniewska-Napierała, Budzet obywatelski jako nowy instrument partycypacji społecznej na obszarach wiejskich w Polsce, «Studia Obszarów Wiejskich» 2019, No. 53.

V. Lowndes, Management Change in Local Governance, [in:] G. Stoker (ed.), The New Management of British Local Governance, MacMillan Press, London 1999.

V. Lowndes, Instytucjonalizam, [in:] D. Marsh, G. Soker (eds.), Teorie i metody w naukach politycznych, Wydawnictwo Uniwersytetu Jagiellońskiego, Kraków 2006.

J.G. March, J.P. Olsen, Elaborating the "New Institutionalism", [in:] R.E. Goodin (ed.), The Oxford Handbook of Political Science, Oxford University Press, Oxford-New York 2011.

A. Mazeaud, M. Nonjon, The Participatory Democracy Market in France: Between Standarization and Fragmentation, [in:] L. Bherer, M. Gauthier, L. Simard (eds.), The Professionalization of Public Participation, Routledge, New York 2017.

F. Montambeault, The Politics of Local Participatory Democracy in Latin America: Institutions, Actors, and Interactions, Stanford University Press, Stanford 2016.

C. Navarro, J. Font, The Biased Inclusiveness of Local Democratic Innovations: Vehicles or Obstacles for Political Equality?, [in:] B. Geissel, M. Joas (eds.), Participatory Democratic Innovations in Europe: Improving the Quality of Democracy?, Verlag Barbara Budrich, Opladen-Berlin-Toronto 2013.

C. Offe, Designing institutions for East European transitions, Reihe Politikwissenschaft / Institut für Höhere Studien, Abt. Politikwissenschaft, 19, Institut für Höhere Studien (IHS), Wien 1994, https://nbn-resolving.org/urn:nbn:de:0168-ssoar-267177 (accessed: 12.01.2020).

C. Offe, Institutional Design, [in:] P. Barry Clarke, J. Foweraker (eds.), Encyclopedia of Democratic Thought, Routledge, London-New York 2001.

C. Pateman, Participatory Democracy Revisited, «Perspectives on Politics» 2012, No. 10 (1).

S. Pawłowski, Konsultacje obligatoryjne i fakultatywne $w$ ustawie o planowaniu $i$ zagospodarowaniu przestrzennym a zakres uspołecznienia procesów planowania przestrzennego, «Ruch Prawniczy, Ekonomiczny i Socjologiczny» 2015 LXXVII - Vol. 1.

M. Pszczyński, P. Sobczyk, Nowelizacja przepisów samorządowych i wyborczych - aspekty prawne i praktyczne istotne dla jednostek samorzadu gminnego, «Ekspertyzy i Opracowania» 2018, No. 38, Narodowy Instytut Samorządu Terytorialnego.

A. Ptak, Lokalna społeczność $w$ procesie tworzenia funduszu soteckiego, «Studia Regionalne i Lokalne» 2015, No. 1 (59).

B. Pytlik, Budżet partycypacyjny w Polsce. Ewolucja i dylematy, «Studia z Polityki Publicznej» 2017, No. 1.

K.S. Quick, M.S. Feldman, Distinguishing Participation and Inclusion, «Journal of Planning Education and Research» 2011, No. 31 (3).

L. Robinson, J. Phillips (et al.), What Motivates Citizens to Participate? Report, The Digital Public Squere, Munt School of Global Affairs, The University of Toronto, Toronto 2016, https://digitalpublicsquare.com/media/DPS-Motivational-Reportv9.pdf (10.01.2020).

S. Royo, A. Yetano, B. Acerete, Citizen Participation in German and Spanish Local Governments: A Comparative Study, «International Journal of Public Administration» 2011, No. 34 (3).

S. Russack, Pathways for Citizens to Engage in EU Policymaking, «Policy Insight. Thinking Ahead of Europe» 2018, No. 14 (November).

D. Rybińska, Instytucja budżetu obywatelskiego jako narzędzia rozwoju samorządu lokalnego, «Finanse i Prawo Finansowe» 2018, No. 1(17). 
P. Sadura, K. Murawska, Z. Włodarczyk, Wieś w Polsce. Diagnoza i prognoza. Raport z badania, Fundacja Wspomagania Wsi, Warszawa 2017.

M. Salvador, C. Ramió, Institutional Design of Citizen Participation in Local Administration: Reflections from a Case Study, «Revista del CLAD Reforma y Democracia» 2012, No. 53 (53).

V.A. Schmidt, Give Peace a Chance: Reconciling Four (Not Three) 'New Institutionalisms', Department of International Relations Boston University, Boston, 2006. Paper prepared for presentation for the Annual Meetings of the American Political Science Association (Philadelphia, PA, 31 August - 3 September 2006).

R. Schröter, Quo Vadis - Citizen Participation in Germany, «International Journal of Deliberative Mechanisms in Science» 2016, No. 4 (1).

G. Smith, Democratic Innovations. Designing Institutions for Citizen Participation, Cambridge University Press New York 2009.

M.C. Stuttaford, T. Boulle, H.J. Haricharan, Z. Sofayiya, Public and Patient Involvement and the Right to Health: Reflections from England, «Frontiers in Sociology» 2017, No. 2.

M. Turcotte, Social engagement and civic participation: Are rural and small-town populations really at an advantage?, «Rural and Small Town Canada Analysis Bulletin Catalogue» 2005, No. 6(4) 21-006-XIE V.

M. Wenclik, Prawne i pozaprawne uwarunkowania konsultacji spotecznych, Państwowa Wyższa Szkoła Informatyki i Przedsiębiorczości w Łomży, Łomża 2016.

E. Zielińska, D. Kraszewski, Narzędzia partycypacji lokalnej w Polsce w latach 2014-2017. Konsultacje społeczne, inicjatywa lokalna, inicjatywa uchwatodawcza, Fundacja im. Stefana Batorego, Warszawa 2019. 